\title{
Antiproliferative and Antioxidant Studies of Anthocephalus cadamba (Roxb.) Miq. Bark
}

\author{
N. FATIMA ${ }^{1}$, M. K. AHMAD¹, J. A. ANSARI ${ }^{1}$, H. J. KHAN¹, N. RASTOGI ${ }^{1}$, S. K. SRIVASTAVA ${ }^{2}$, S. AHMAD ${ }^{3}$ AND Z. ALI $^{*}$
}

Department of Chemistry, Integral University, Lucknow-226 026, ${ }^{1}$ Natural Products Research Lab, Department of Biochemistry, King George's Medical University, Lucknow-226 003, 2Department of Pharmacognosy, CSIRNational Botanical Research Institute, Lucknow-226 001, 3State Government T.T. college and Hospital, Lucknow-226 003, India

\section{Fatima, et al.: Anticancer Studies of Anthocephalus cadamba Bark}

\begin{abstract}
The present study was conducted on Anthocephalus cadamba (Roxb.) Miq. bark methanol extract to evaluate antiproliferative and antioxidant studies along with presence of total phenolic contents. These interferences were accomplished by 3-(4,5-dimethylthiazol-2-yl)-2,5-diphenyltetrazolium bromide assay, colony formation assay, radical scavenging assay (1,1-diphenyl-2-picrylhydrazyl and (2,2'-azinobis(3-ethylbenzthiazoline6-sulfonate)) and Folin-Ciocalteu reagent method. Results obtained demonstrated that $A$. cadamba bark methanol extract shown significant antiproliferative activity $\left(\mathrm{IC}_{50}=319 \pm 4.98 \mu \mathrm{g} / \mathrm{ml}\right)$ against human cervical cancer cells as compared with standard cisplatin $\left(\mathrm{IC}_{50}=\mathbf{5 . 6} \pm 0.52 \mu \mathrm{g} / \mathrm{ml}\right) \mathrm{drug}$. The high antiradical activity demonstrated by extract against 1,1-diphenyl-2-picrylhydrazyl and 2,2'-azinobis(3-ethylbenzthiazoline-6sulfonate) free radicals was compared with standards ascorbic acid, quercetin and rutin. The high amount of total phenolic contents showed phytochemical potency of $A$. cadamba. The antiproliferative activity of $A$. cadamba bark methanol extract may be due to induction of apoptosis which is credited to the phenolic contents. Therefore, further in depth studies are needed to scrutinize the molecular based mechanism involved in antiproliferative activity of $A$. cadamba bark along with isolation and identification of active principles.
\end{abstract}

Key words: Anthocephalus cadamba, human cervical cancer, antioxidant, total phenolic content

Cancer is defined as a complex disease characterized by an uncontrolled growth of cells. Among various types of cancers, carcinoma of cervix is a major health threat and one of the most common gynecological malignancies worldwide. Approximately 500000 new cases of cervical cancer are diagnosed each year, with 280000 deaths worldwide, making it the second most common malignancy affecting women worldwide ${ }^{[1]}$.

In Indian scenario, women aged $15 \mathrm{y}$ and older are 436.76 million and are at the risk of developing cervical cancer. Yearly around 122844 women are diagnosed with cervical cancer and out of which $67477 \mathrm{die}^{[2]}$. The common modalities of cervical cancer treatment include chemotherapy, radiotherapy and surgery with low rates of complete response and adverse side effects ${ }^{[3]}$. Therefore, there is an imperative need to generate innovative therapeutic strategies for cancer treatment, which act by modulating cell proliferation, lowering the risk of malignancy, promoting cytostatic effects and blocking or delaying the progression of tumorigenesis ${ }^{[4]}$. One such approach is use of traditional medicines which have been recognized in the management of various diseases since ancient times. A number of promising leads have been isolated and identified from medicinal plants. Among different phytochemicals, polyphenols have gained significant focus due to their various pharmacological benefits ${ }^{[5]}$.

India has a vast diversity and culture of medicinal plants known as Indian Ayurvedic system of Medicine (IASM) worldwide. Anthocephalus cadamba (Roxb.) Miq. (Rubiaceae) is one of the most precious medicinal evergreen tropical tree native to South and Southeast Asia. As a traditional medicine, it is used for various

This is an open access article distributed under terms of the Creative Commons Attribution-NonCommercial-ShareAlike 3.0 License, which allows other the remix, tweak, and build up to the non-commercially, as long as the author is credited and the new creations are licensed under the identical terms.

Accepted 31 August 2016

Revised 31 August 2016

Received 20 March 2016

Indian J Pharm Sci 2016;78(4):525-531 
ailments such as fever, uterine complaints, skin diseases, inflammation, anemia, dysentery, leprosy ${ }^{[6,7]}$. The bark of $A$. cadamba is reported to have astringent, febrifugal, digestive, carminative, diuretic, expectorant, constipating, antiemetic and antiinflammatory properties $^{[8-14]}$.

Despite several known pharmacological properties of $A$. cadamba, only few studies are available on antiproliferative activity of $A$. cadamba bark ${ }^{[15,16]}$. However, to the best of our knowledge, no scientific data are available on the antiproliferative activity of $A$. cadamba bark against human cervical cancer cells. Therefore, the present study was carried out to screen the antiproliferative effect of $A$. cadamba bark methanol extract against human cervical cancer HeLa cells and free radical scavenging activity for antioxidant potential along with total phenolic contents.

\section{MATERIALS AND METHODS}

2,2-diphenyl-1-picrylhydrazyl (DPPH), 2,2'-azinobis(3-ethylbenzothiazoline-6-sulphonic acid) (ABTS) and Folin-Ciocalteu reagents were procured from Sigma Aldrich, USA. Ascorbic acid, rutin, quercetin, methanol and others chemicals used in study were obtained from Merck. Fetal bovine serum (FBS), phosphate buffered saline (PBS) and Dulbecco's Modified Eagle's Medium (DMEM) were purchased from Gibco BRL, USA). Penicillin and streptomycin were purchased from Lonza, USA. 3-[4, 5-dimethyl-2thiazolyl]-2, 5-diphenyltetrazolium bromide (MTT), trypsin-EDTA and Coomassie blue were obtained from Sigma Aldrich, USA. Dimethyl Sulfoxide (DMSO) was purchased from Calbiochem. Double distilled water was used for cleaning of glassware.

\section{Collection of plant material and preparation of plant extract:}

The bark of $A$. cadamba was collected from campus of King George's Medical University, Lucknow, India. The plant was identified at Department of Pharmacognosy, NBRI, Lucknow, India.

The collected $A$. cadamba bark was air dried and ground to fine powder. The powdered plant material was percolated in 95\% methanol and kept for $72 \mathrm{~h}$ at room temperature. After $72 \mathrm{~h}$, extract was filtered and combined extract was concentrated under reduced pressure at controlled temperature on a rotatory evaporator. This process repeated 3-4 times for complete extraction. Residue obtained was dried completely and labelled as ACBM (A. cadamba bark methanol extract) and kept in desiccator for further study.

\section{Cell culture:}

Human cervical carcinoma HeLa cell line was obtained from cell repository of National Centre for Cell Sciences, Pune, India. HeLa cells were cultured in Minimum Essential Medium Eagle (MEM) supplemented with $2.0 \mathrm{mM}$ L-glutamine, $1.5 \mathrm{~g} / 1 \mathrm{NaHCO}_{3}, 0.1 \mathrm{mM}$ nonessential amino acids, and $1.0 \mathrm{mM}$ sodium pyruvate and supplemented to contain $10 \% \mathrm{v} / \mathrm{v}$ Fetal Calf Serum. Cells were cultured in a healthy condition and exponentially growing cells were used for experiments.

\section{Cell proliferation assay/MTT assay:}

The antiproliferative potential of ACBM was carried out by MTT assay against HeLa cell line. ACBM (100 $\mathrm{mg}$ ) was dissolved in $1000 \mu \mathrm{l}$ of DMSO. Then $10 \mu \mathrm{l}$ of this solution was diluted to $90 \mu 1$ of DMEM to make the final concentration of $10 \mathrm{mg} / \mathrm{ml}$. Then by serial dilution varying concentrations were prepared for the working stock. Thus the concentration of the solutions obtained was $12.5-400 \mu \mathrm{g} / \mathrm{ml}$. For cytotoxicity assay, HeLa cells were seeded in 96 well plate (5000 cells per well) and cultured at $37^{\circ}$ for $24 \mathrm{~h}$. After $24 \mathrm{~h}$ cells were treated with serial concentrations of ACBM as well as cisplatin $(1.25-40 \mu \mathrm{g} / \mathrm{ml})$ which is used as standard, in triplicates. At the end of treatment $10 \mu \mathrm{l}$ of MTT $(5.0 \mathrm{mg} / \mathrm{ml}$ in PBS) was added to each wells and further incubated for 3-4 h. After incubation medium containing MTT was gently aspirated and cells were washed twice with PBS and DMSO (100 $\mu \mathrm{l} /$ well $)$ reagent was added to dissolve the formazan crystal. Absorbance was measured by a microtiter plate reader (Synergy HT; Bioteck) at $540 \mathrm{~nm}$.

\section{Evaluation on morphological changes:}

Morphological analysis of HeLa cells after ACBM treatments was performed to study the changes induce by extract. In brief, HeLa cells were grown to $70 \%$ confluency and treated with different concentrations $(12.5 \mu \mathrm{g} / \mathrm{ml}$ to $400 \mu \mathrm{g} / \mathrm{ml})$ of ACBM. The medium was discarded and treated cells were washed once with PBS. The morphological changes of apoptotic cells were observed using phase contrast inverted microscope at $10 \times$ magnification.

\section{Clonogenic assay:}

Clonogenic assay is used to study the effect of drugs on the long term survival and proliferation of cancer cells which is based on the ability of single cell to grow into colony ${ }^{[17]}$. In this assay, 200 cells/well were 
seeded in the 6 well plate and after $24 \mathrm{~h}$ of incubation, $\mathrm{HeLa}$ cells were treated with different concentrations of ACBM (25 $\mu \mathrm{g} / \mathrm{ml}$ to $400 \mu \mathrm{g} / \mathrm{ml})$ and DMSO (0.5\%, Control) for $24 \mathrm{~h}$. After $24 \mathrm{~h}$ of treatment old medium was discarded and fresh complete growth medium was added. Medium (DMEM containing 5\% FBS) was changed every 3 days to sustain the viability of cells and the propagation to form visible colonies. Colonies formed after 7 days were fixed with methanol, stained with $0.05 \%$ Coomassie blue and counted under an inverted microscope.

\section{Total phenolic content:}

Total phenolic content of ACBM was estimated by Folin-Ciocalteau reagent method determined by Singleton and Rossi with slight modifications ${ }^{[18]}$. In brief, $0.5 \mathrm{ml}$ of ACBM $(1 \mathrm{mg} / \mathrm{ml})$ was added to 2.5 $\mathrm{ml} \mathrm{10 \%} \mathrm{Folin-Ciocalteu} \mathrm{reagent} \mathrm{and} \mathrm{incubates} \mathrm{for} \mathrm{five}$ minute. After five minute, $2.5 \mathrm{ml}$ solution of $\mathrm{Na}_{2} \mathrm{CO}_{3}$ $(10 \% \mathrm{w} / \mathrm{v}$ in distilled water) was added and allowed to stand for $15 \mathrm{~min}$ at $25^{\circ}$ with alternating shaking. The absorbance was measured at $765 \mathrm{~nm}$ using a double beam UV/Vis spectrophotometer. Same procedure was done with blank consisted of all reagents and solvents but without the sample. The same procedure was repeated for the standard solution of gallic acid and the calibration curve was plotted. The total concentration of phenolic content in the tested fractions was determined as mg GAE/g dry extract.

\section{DPPH radical scavenging activity:}

DPPH radical scavenging effect was carried out by the method described by Brand-Williams with slight modification ${ }^{[19]}$. ACBM extract and standards (ascorbic acid, rutin and quercetin) were dissolved in methanol to make a $1.0 \mathrm{mg} / \mathrm{ml}$ of stock solution. Different working concentrations of ACBM $(12.5 \mu \mathrm{g} / \mathrm{ml}$ to $400 \mu \mathrm{g} / \mathrm{ml})$ were prepared from stock solution in $1.0 \mathrm{ml}$ volume in a test tube. Then $1.0 \mathrm{ml}$ of DPPH solution added to each test tube and was shaken gently. The samples were kept in the dark for 15 min at room temperature and the decrease in absorbance was measured at $517 \mathrm{~nm}$ using UV/Vis spectrophotometer. All the samples were analyzed in triplicate. The absorbance was recorded for each concentration and percent quenching of DPPH was calculated.

Radical scavenging activity $(\%)=\left(\mathrm{A}_{0}-\mathrm{A}_{1} / \mathrm{A}_{0}\right) \times 100$, where $A_{0}$ was the absorbance of the blank and $A_{1}$ was the absorbance of compound.

\section{ABTS radical scavenging activity:}

Theantioxidant potentialofACBMwas furthermeasured by using double beam UV/Vis spectrophotometer (Systonics) by improved ABTS method with slight modifications $^{[20,21]}$. The ABTS radical cation (ABTS ${ }^{\bullet+}$ ) solution was prepared by the mixing of $7 \mathrm{mM}$ ABTS and $2.45 \mathrm{mM}$ potassium per-sulphate, after incubation at $27^{\circ}$ in the dark for $16 \mathrm{~h}$. The radical was stable in this form for more than two days when stored in the dark at room temperature. ABTS solution was diluted with methanol to obtain the absorbance of $0.7 \pm 0.005$ units at $750 \mathrm{~nm}$. The difference concentration (12.5$400 \mu \mathrm{g} / \mathrm{ml}$ ) of ACBM was prepared in methanol. $3.9 \mathrm{ml} \mathrm{ABTS}^{\bullet+}$ solution (absorbance $=0.700 \pm 0.005$ ) was added to $0.1 \mathrm{ml}$ of the different concentrations of ACBM and mixed thoroughly. The reaction mixture was allowed to stand at $27^{\circ}$ for $6 \mathrm{~min}$ and the absorbance at $734 \mathrm{~nm}$ was immediately recorded. Ascorbic acid, rutin and quercetin were used as positive control. All determinations were carried out in triplicate. ABTS free radical scavenging activity was calculated using the formula, ABTS radical scavenging activity $(\%)=\left(A_{\text {control }}-A_{\text {test }}\right) / A_{\text {control }} \times 100$, where $A_{\text {control }}$ is the absorbance of ABTS radical+methanol; $A_{\text {test }}$ is the absorbance of ABTS radical+sample extract/ standard.

\section{Statistical analysis:}

Data were expressed as the mean values \pm SD and were obtained from experiments repeated at least three times. Statistically analysis was performed by one-way analysis of variance (ANOVA) following by Dunnett's test. P-values less than 0.05 were considered significant.

\section{RESULTS AND DISCUSSION}

In the present study, the antiproliferative effect of $A C B M$ was evaluated against human cervical cancer HeLa cell line through MTT and colony formation assay. The cells were treated with increasing dose of ACBM for 24, 48 and $72 \mathrm{~h}$ (fig. 1). The ACBM caused inhibition of $3.97 \pm 0.74 \%$ to $54.92 \pm 1.25 \%$ in HeLa cells at the concentration ranging from $12.5 \mu \mathrm{g} / \mathrm{ml}$ to $400 \mu \mathrm{g} / \mathrm{ml}$ after exposure to $24 \mathrm{~h}$. Similarly, ACBM demonstrated $4.76 \pm 1.64 \%$ to $56.98 \pm 2.87 \%$ and $6.65 \pm$ 1.86 to $57.98 \pm 7.24 \%$ of inhibition at similar dose for the treatment of 48 and $72 \mathrm{~h}$, respectively. Indexing of fifty percent killing $\left(\mathrm{IC}_{50}\right)$ of $\mathrm{HeLa}$ cells revealed that ACBM at a concentration of $319 \pm 4.98 \mu \mathrm{g} / \mathrm{ml}$ for $24 \mathrm{~h}$, $282 \pm 5.67 \mu \mathrm{g} / \mathrm{ml}$ for $48 \mu \mathrm{g} / \mathrm{ml}$ and $254 \pm 2.85 \mu \mathrm{g} / \mathrm{ml}$ for $72 \mathrm{~h}$ inhibited fifty percent of cells. The results were 
compared with standard drug cisplatin which showed an $\mathrm{IC}_{50}$ value at a concentration of $5.6 \pm 0.52 \mu \mathrm{g} / \mathrm{ml}$ followed by $24 \mathrm{~h}$ exposure. The above findings showed that ACBM exhibited significant inhibitory activity on HeLa cancer cells.

To further confirm the antiproliferative effect of ACBM against HeLa cells, we further investigated the effect of ACBM on formation of colonies of HeLa cells. Results showed that, the growth and number of colony foci were decreased after treatment with different concentration $(25 \mu \mathrm{g} / \mathrm{ml}-400 \mu \mathrm{g} / \mathrm{ml})$ of ACBM in HeLa cells when compared with untreated control (fig. 2). Moreover, statistical analysis demonstrated that the mean sizes of the control colonies were larger than those of the ACBM-treated group. At the concentration range from $25 \mu \mathrm{g} / \mathrm{ml}$ to $400 \mu \mathrm{g} / \mathrm{ml}$ colony inhibition rate of ACBM treated HeLa cells was $12.53 \pm 1.78 \%$ to $60.54 \pm 3.87 \%$

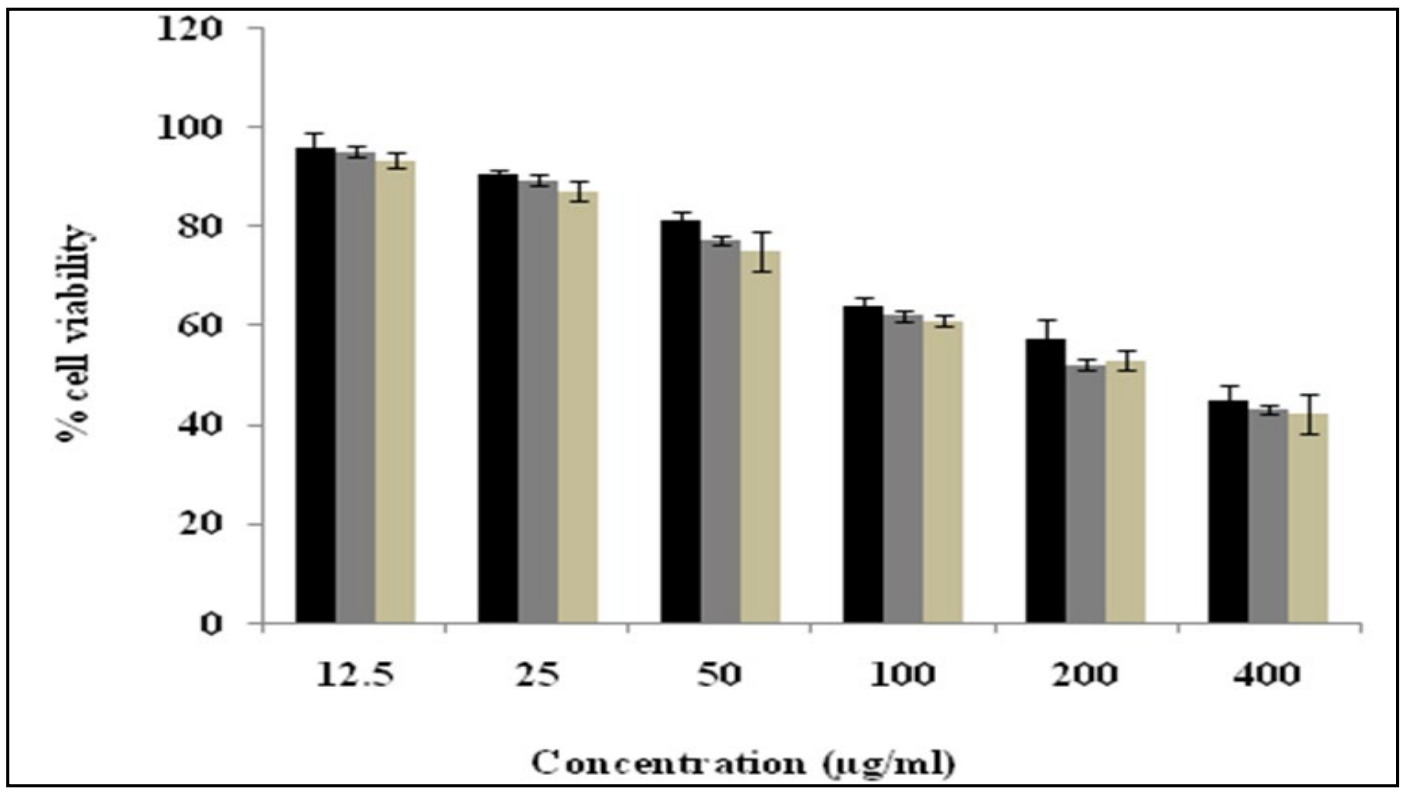

Fig. 1: ACBM inhibited proliferation in human cervical cancer (HeLa) cells.

Cell viability in treated cells versus untreated cells was analyzed by MTT assay after $24(\square), 48$ ( $\square$ ) and 72 h ( $\square$ ) of incubation. The data were represented as the mean $\pm S D$ of the results of three independent experiments.

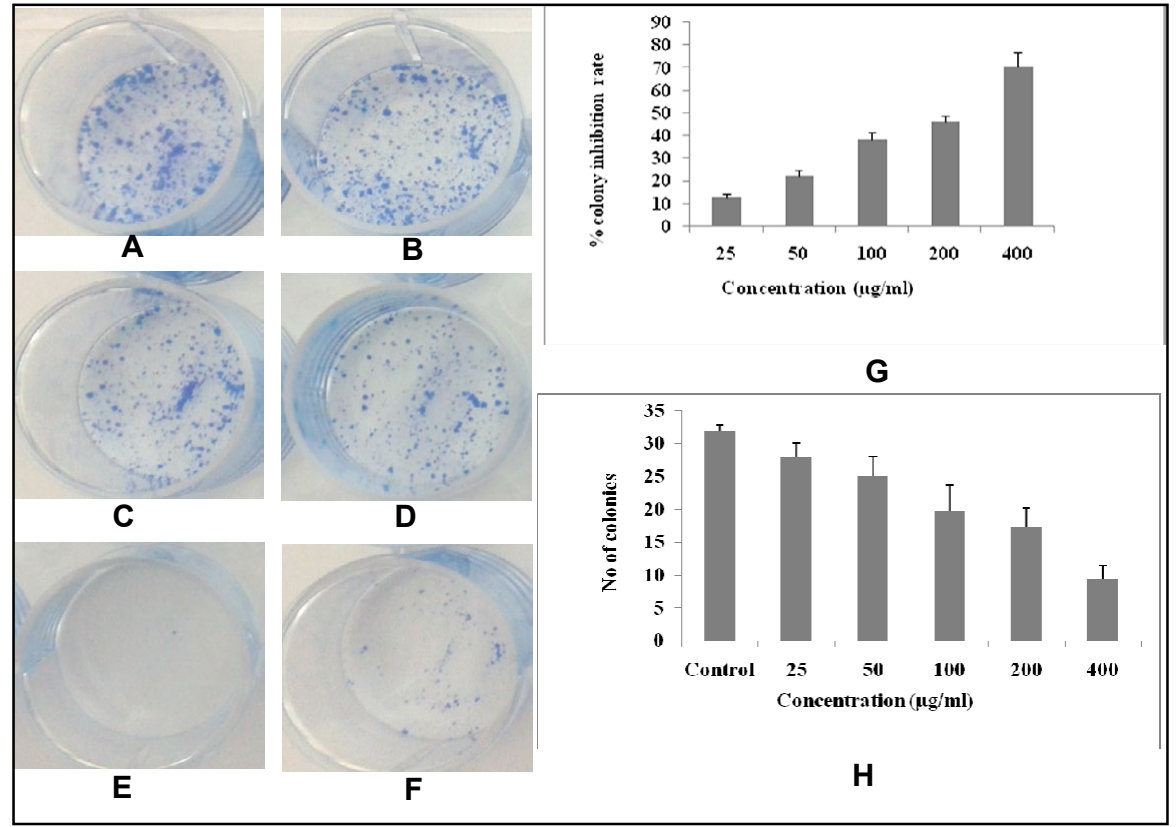

Fig. 2: ACBM inhibited colony formation in human cervical cancer (HeLa) cells.

Cells were seeded into 6 well plate at the density of 200 cells per well, treated with various concentrations of ACBM for 24 h. Fixed and stained with $4 \%$ paraformaldehyde and $0.05 \%$ Coomassie blue after 7 days. (A) Control; (B) $25 \mu \mathrm{g} / \mathrm{ml}$; (C) $50 \mu \mathrm{g} / \mathrm{ml} ;$ (D) 100 $\mu \mathrm{g} / \mathrm{ml}$; (E) $200 \mu \mathrm{g} / \mathrm{ml}$; (F) $400 \mu \mathrm{g} / \mathrm{ml}$. At different concentration of ACMB treated HeLa cells the colony inhibition rate compared to untreated cells is represented in fig. $2 \mathrm{G}$. and number of colonies present in assay given in fig. $2 \mathrm{H}$. 
when compared to untreated cells (fig. 2). The result of clonogenic assay was consistent with the results of MTT assay, indicating that ACBM effectively possess antiproliferative activity against human cervical carcinoma cells.

Morphological alternation in the HeLa cells after exposure of ACBM was observed under phase contrast microscope. Cells undergoing apoptosis display distinctive features in morphological changes such as loss of cell membrane symmetry and attachment, chromatin condensation, cell shrinkage and nuclear fragmentation. It is clearly demonstrated in fig. 3 that at high concentration of ACBM, enlargement of cells was conspicuously seen and ballooning was apparent in the HeLa cells. At the highest concentration of treatment (200-400 $\mu \mathrm{g} / \mathrm{ml})$, the cells become shrunken, rounded and showed detachment from the surface of 96 well denote sign of cell death (fig. 3 ).

Based on the results obtained from MTT and colony inhibition assay, it is evident that ACBM exhibited significant time and dose dependent antiproliferative effect on HeLa cells. Furthermore, morphology assessment of ACBM treated vs. untreated HeLa cells revealed typical features of cells undergoing apoptosis such as loss of cell membrane symmetry, detachment from surface, cell shrinkage. These observations are in concordance with earlier reports that showed the cytotoxic property of $A$. cadamba ${ }^{[15,16]}$. A recent report by Dolai et al. showed that ACBM decrease in the tumor volume, viable cell count, tumor weight and elevated the life span of Ehrlich ascites carcinoma tumor bearing mice ${ }^{[12]}$. These assays hold assurance for further in vitro and in vivo molecular target-oriented studies to unveil the mechanism of chemoprotective effects of ACBM in human cervical cancer.

Free radicals such as reactive oxygen species (ROS), reactive nitrogen species (RNS) are highly linked with various oxidative stress related diseases including cancer ${ }^{[22]}$. Hence, we attempted to evaluate the free radical inhibitory properties of ACBM. We observed that ACBM inhibited DPPH free radical from $18.65 \pm 0.98 \%$ to $80.54 \pm 2.34 \%$ at the treatment concentrations of 12.5 to $400 \mu \mathrm{g} / \mathrm{ml}$. However, the fifty percent inhibition $\left(\mathrm{IC}_{50}\right)$ of $\mathrm{DPPH}$ was noted at $93.43 \pm 2.36 \mu \mathrm{g} / \mathrm{ml}$ concentration (fig. 4 ). The inhibitory efficiency of ACBM was compared with ascorbic acid, rutin and quercetin standards which showed $\mathrm{IC}_{50}$ value at a concentration of $2.04 \pm 0.71,6.61 \pm 0.41$ and $8.36 \pm 0.46 \mu \mathrm{g} / \mathrm{ml}$ respectively. Similarly, the results from ABTS showed that ACBM inhibited ABTS free radical from $9.76 \pm 1.98 \%$ to $90.15 \pm 0.25 \%$ inhibition at a concentration from 12.5 to $400 \mu \mathrm{g} / \mathrm{ml}$. However, the $\mathrm{IC}_{50}$ value of ACBM was calculated $77.82 \pm 2.98$ $\mu \mathrm{g} / \mathrm{ml}$. The result was further compared with ascorbic acid, rutin and quercetin as standards with $\mathrm{IC}_{50}$ value of $10.2 \pm 0.52,4.31 \pm 0.56$ and $6.41 \pm .056 \mu \mathrm{g} / \mathrm{ml}$, respectively.

There are numerous reports on natural agents having chemotherapeutic properties possesses high antiradical and antioxidant properties ${ }^{[23-25]}$. High concentration

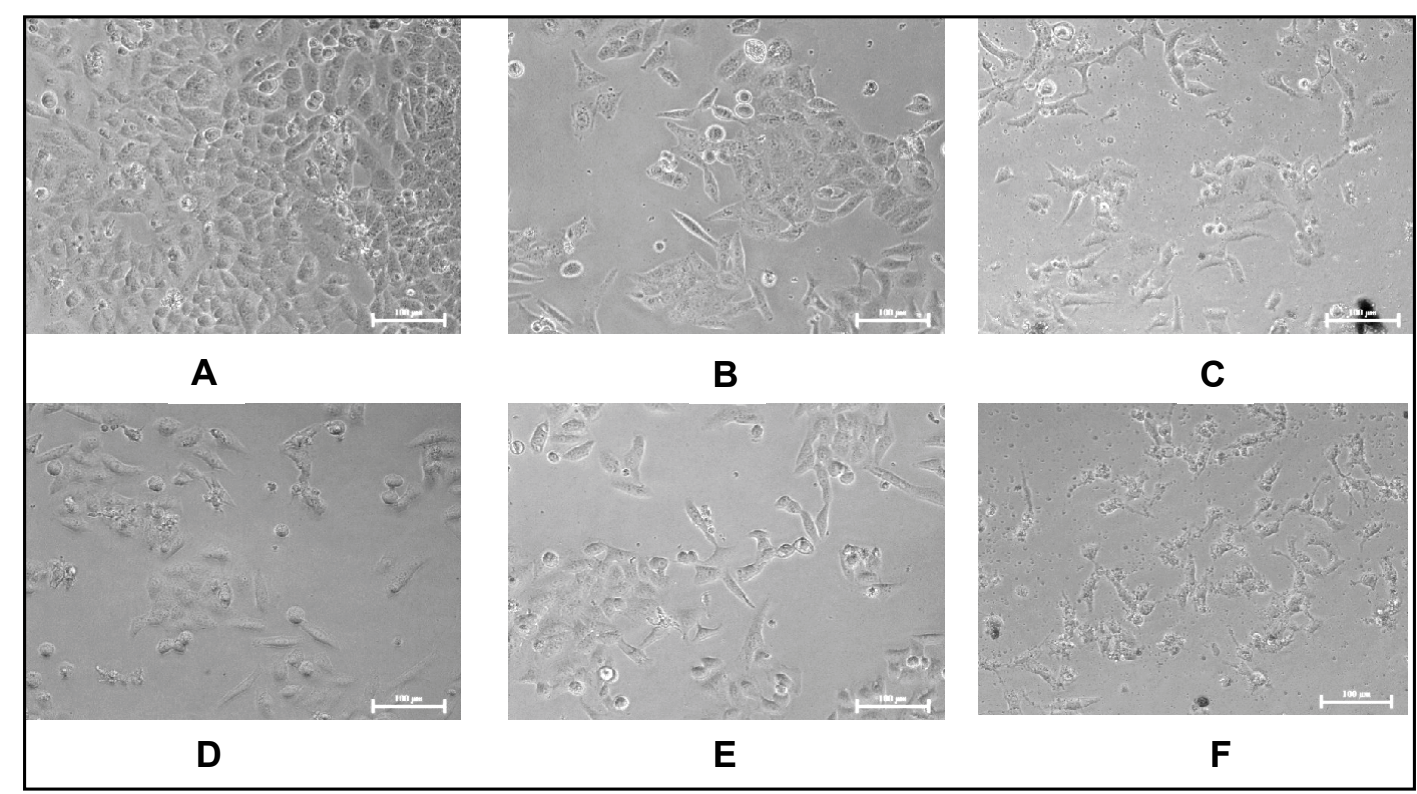

Fig. 3: Morphological changes of HeLa cells after treatment with ACBM.

Morphological changes of HeLa cells after treatment with ACBM for $24 \mathrm{~h}$ and imaged by inverted phase contrast microscope. (A) Control; (B) $25 \mu \mathrm{g} / \mathrm{ml}$; (C) $50 \mu \mathrm{g} / \mathrm{ml}$; (D) $100 \mu \mathrm{g} / \mathrm{ml}$; (E) $200 \mu \mathrm{g} / \mathrm{ml}$; (F) $400 \mu \mathrm{g} / \mathrm{ml}$. 
www.ijpsonline.com

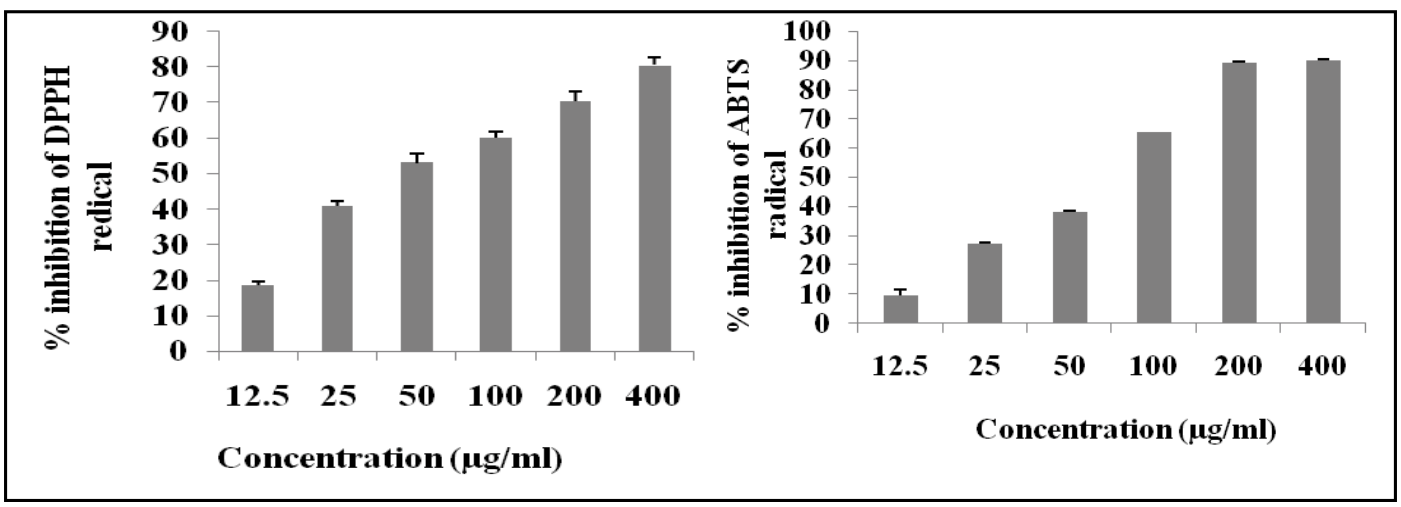

Fig. 4: Percent inhibition of DPPH and ABTS radicals after treatment with ACBM.

Percent inhibition of DPPH (a) and ABTS (b) radicals after treatment with ACBM. The data were represented as the mean \pm SD of the results of three independent experiments.

of free radicals exerts deleterious effects on all major components of cells, including DNA, proteins and cell membranes. These free radicals initiated damage may play role in the development of cancer ${ }^{[26]}$. Many studies have shown that presence of exogenous antioxidants prevents free radical damage associated with cancer development ${ }^{[27,28]}$. A clinical trial study was conducted by Blot et al. showed that people who took antioxidant supplements had a lower risk of death from gastric cancer ${ }^{[29]}$. Similarly, supplementation with Vitmain C, $\mathrm{E}$ and minerals was associated with lower total cancer incidence ${ }^{[30-32]}$. It has been reported that the dietary phytochemicals can slow down the different stages of the progression of carcinogenesis ${ }^{[33,34]}$. As we found the antiproliferative and antioxidant potential of ACBM, it can be coincide with earlier studies that the high antiradical/antioxidant property of natural agents play significant role in cancer inhibition or proliferation as well as cancer incidence.

Among different phytochemicals, phenolics are suggested to be the major bioactive compounds for the health benefits and accounted for various pharmacological properties ${ }^{[22]}$. Our results showed that ACBM have $17.9 \mathrm{mg} \mathrm{GAE} / \mathrm{g}$ of plant extract total phenolics content. Dietary polyphenols may exert their antiproliferative effects through a number of possible mechanisms, such as exclusion of carcinogenic agents, modulation of cancer cell signaling and antioxidant enzymatic activities, and initiation of apoptosis as well as of cell cycle arrest ${ }^{[35]}$. In summary, our study is consistent with other studies demonstrating that $A$. cadamba has potent antiproliferative and antioxidant properties, as well as presence of different types of phenolic compounds ${ }^{[14,36]}$.

In conclusion, the results of the present study demonstrated antiproliferative and antioxidant potential of A. cadamba and presence of phenolic contents. The antiproliferative activity of ACBM may be due to induction of apoptosis in human cervical cancer cells. Overall study fascinates the potent features of ACBM as chemotherapeutic agent. Therefore, further in depth studies are needed to explore the molecular mechanisms involved in antiproliferative activity of ACBM along with isolation and identification of active principles.

\section{Acknowledgements:}

The author would like to thank Department of Science and Technology (DST), New Delhi for providing financial grant (SR/WOS-A/CS-109/2013) for supporting this research.

\section{Financial support and sponsorship:}

Nil.

\section{Conflicts of interest:}

There are no conflicts of interest.

\section{REFERENCES}

1. Bhattacharjya H, Sarkar M, Luwang N. Knowledge and practice regarding prevention of cervical cancer among women attending a tertiary care centre of Tripura. Int J Community Med Public Health 2015;2:176-9.

2. Bruni L, Barrionuevo-Rosas L, Albero G, Aldea M, Serrano $\mathrm{B}$, Valencia S, et al. ICO Information Centre on HPV and Cancer (HPV Information Centre). Human Papillomavirus and Related Diseases in India. Summary Report 2015;12-23.

3. Robati M, Holtz D, Dunton CJ. A review of topotecan in combination chemotherapy for advanced cervical cancer. Ther Clin Risk Manag 2008;4:213-8.

4. Sa G, Das T. Anticancer effects of curcumin: cycle of life and death. Cell division 2008;3:14.

5. Zhou K, Yu L. Total phenolic content and antioxidant 
properties of commonly consumed vegetables grown in Colorado. LWT-Food Sci Technol 2006;39:1155-62.

6. Bhandary MJ, Chandrashekar KR, Kaveriappa KM. Medical ethnobotany of the Siddis of Uttara Kannada district Karnataka. J Ethnopharmacol 1995;47:149-58.

7. Mondal S, Dash GK, Acharyya S. Analgesic, antiinflammatory and antipyretic studies of Neolamarckia cadamba barks. J Pharm Res 2009;2:1133-6.

8. Mondal S, Dash GK, Acharyya A, Acharyya S, Sharma HP. Studies on diuretic and laxative activity of bark extracts of Neolamarckia cadamba (Roxb.) Bosser. Drug Invent Today 2009;1:78-80.

9. Alekhya V, Deepan T, Sahoo S, Dhanaraju MD. Preliminary phytochemical screening and evaluation of in vitro antioxidant activity of Anthocephalous cadamba by using solvent extracts. Eur J Biol Sci 2013;5:34-7.

10. Alam MA, Akter R, Subhan N, Rahman MM, Majumder MM, Nahar L, et al. Antidiarrhoeal property of the hydroethanolic extract of the flowering tops of Anthocephalus cadamba. Rev Bras Farmacogn 2008;18:155-9.

11. Kumar V, Mahdi F, Chander R, Singh R, Mahdi AA, Khanna AK, et al. Hypolipidemic and antioxidant activity of Anthocephalus indicus (Kadam) root extract. Indian J Biochem Biophys 2010;47:104-9.

12. Dolai N, Karmakar I, Suresh Kumar RB, Kar B, Bala A, Haldar PK. Evaluation of antitumor activity and in vivo antioxidant status of Anthocephalus cadamba on Ehrlich ascites carcinoma treated mice. J Ethnopharmacol 2012;142:865-70.

13. Dolai N, Kumara U, Islam A, Haldar PK. Inhibitory effects of Anthocephalus cadamba stem bark fractions intercede antiinflammatory and carbon tetrachloride induced hepatotoxicity in rats. Orient Pharm Exp Med 2015;2:123-34.

14. Chandrashekar KS, Abinash B, Prasanna KS. Antiinflammatory effect of the methanol extract from Anthocephalus cadamba stem bark in animal models. Int J Plant Biology 2010;1:30-32.

15. Hassan MA, Ferdous MA, Chowdherry R, Khan KA. Evaluation of analgesic, antihelmintic and cytotoxic activity of Anthocephalus cadamba. Int J Pharm Sci 2013;11:99-107.

16. Kumar D, Tejaswi C, Rasamalla S, Mallick S, Pala BC. Bio-assay guided isolation of anticancer compounds from Anthocephalus cadamba bark. Nat Prod Commun 2015;10:1349-50.

17. Wang Y, Auyeung KK, Zhang X, Ko JK. Astragalus saponins modulates colon cancer development by regulating calpainmediated glucose-regulated protein expression. BMC Complement Altern Med 2014;14:401.

18. Singeleton VL, Rossi JA. Colorimetry of total phenolics with phosphomolybdic phosphotungstic acid reagents. Am J Enol Vitic 1965;16:144-58.

19. Brand-Williams W, Cuvelier ME, Berset C. Use of free radical method to evaluate antioxidant activity. Lebensm Wiss Techn 1995;28:25-30.

20. Cai Y, Luo Q, Sun M, Corke H. Antioxidant activity and phenolic compounds of 112 traditional Chinese medicinal plants associated with anticancer. Life Sci 2004;74:2157-84.

21. Re R, Pellegrini N, Proteggente A, Pannala A, Yang M, RiceEvans C. Antioxidant activity applying an improved ABTS radical cation decolorization assay. Free Radic Biol Med 1999;26:1231-7.

22. Sun J, Chu YF, Wu X, Liu RH. Antioxidant and antiproliferation activities of common fruits. J Agric Food Chem 2002;50:7449-54.

23. Lamson DW, Brignall MS. Antioxidants in antioxidants in cancer therapy; their actions and interactions with oncologic therapies. Altern Med Rev 1999;4:304-29.

24. Conklin KA. Dietary antioxidants during cancer chemotherapy: impact on chemotherapeutic effectiveness and development of side effects. Nutr Cancer 2000;37:1-18.

25. Mahdi AA, Ansari JA, Khan HJ, Fatima N, Lakshmi V, Ahmad MK, et al. Anticancerous medicinal plants: A review. Int J Adv Pharm Res 2013;4:1706-22.

26. LoboV, Patil A, Phatak A, Chandra N. Free radicals, ntioxidants and functional foods: Impact on human health. Pharmacogn Rev 2010;4:118-26.

27. Patterson RE, White E, Kristal AR, Neuhouser ML, Potter JD. Vitamin supplements and cancer risk: the epidemiologic evidence. Cancer Causes Control 1997;8:786-802.

28. Bouayed J, Bohn T. Exogenous antioxidants--Double-edged swords in cellular redox state: Health beneficial effects at physiologic doses versus deleterious effects at high doses. Oxid Med Cell Longev 2010;3:228-37.

29. Blot WJ, Li JY, Taylor PR, Guo W, Dawsey S, Wang $\mathrm{GQ}$, et al. Nutrition intervention trials in Linxian, China: supplementation with specific vitamin/mineral combinations, cancer incidence, and disease-specific mortality in the general population. J Natl Cancer Inst 1993;85:1483-91.

30. Lin J, Cook NR, Albert C, Zaharris E, Gaziano JM, Van Denburgh $\mathrm{M}$, et al. Vitamins $\mathrm{C}$ and $\mathrm{E}$ and beta carotene supplementation and cancer risk: a randomized controlled trial. J Natl Cancer Inst 2009;10:14-23.

31. Hercberg S, Ezzedine K, Guinot C, Preziosi P, Galan P, Bertrais $\mathrm{S}$, et al. Antioxidant supplementation increases the risk of skin cancers in women but not in men. J Nutr 2007;137:2098-105.

32. Hercberg S, Kesse-Guyot E, Druesne-Pecollo N, Touvier M, Favier A, Latino-Martel P, et al. Incidence of cancers, ischemic cardiovascular diseases and mortality during 5-year follow-up after stopping antioxidant vitamins and minerals supplements: a postintervention follow-up in the SU.VI.MAX Study. Int J Cancer 2010;127:1875-81.

33. Surh YJ. Cancerchemoprevention with dietary phytochemicals. Nat Rev Cancer 2003;3:768-80.

34. Middleton E, Kandaswami C, Theoharides TC. The effects of plant flavonoids on mammalian cells: implications for inflammation, heart disease, and cancer. Pharmacol Rev 2000;52:673-751.

35. Hu ML. Dietary polyphenols as antioxidants and anticancer agents: more questions than answers. Chang Gung Med J 2011;34:449-60.

36. Chandel M, Sharma U, Kumar N, Singh B, Kaur S. Antioxidant activity and identification of bioactive compounds from leaves of Anthocephalus cadamba by ultra-performance liquid chromatography/electrospray ionization quadrupole time of flight mass spectrometry. Asian Pac J Trop Med 2012;5:977-85. 